\title{
Effectiveness of Science Learning through Flash Media and Students' Worksheet
}

\author{
Syamsu \\ Faculty of Teacher Training and Education \\ University of Tadulako \\ Palu, Indonesia \\ Amiruddin Kade \\ Faculty of Teacher Training and Education \\ University of Tadulako \\ Palu, Indonesia
}

\author{
Abdul Rahman \\ Faculty of Teacher Training and Education \\ University of Tadulako \\ Palu, Indonesia \\ amankabdul@gmail.com
}

\begin{abstract}
Abstact - This research intends to identify the effectiveness of Science learning through Flash Media and Students' Worksheet using constructivist approach and reviewed by interest, motivation, and learning achievement of primary school students. This is a quasi-experimental research which the dependent variable is learning interest of Science, learning motivation of Science, and learning achievement of Science. Meanwhile, the independent variable is the use of Flash using constructivist approach of experimental class and students' worksheet media using constructivist approach of control class. Subject of this research is 23 students of experimental class and 18 students of control class. Instrument used to collect data consists of: questionnaire of learning interest of Science, questionnaire of learning motivation of Science, and test of learning achievement of Science. Data are analyzed through descriptive statistic technique to describe the interest, motivation, and learning achievement of students on Science, and inferential statistic through t-test on significant level of $5 \%(\alpha=0,05)$. The result of this research revealed that students' interest is 0,0008 ( $t_{\text {test }}$ ) on significant level of $=0,99$; students' motivation is $\mathbf{- 0 . 3 3}$ ( $t_{\text {test }}$ ) on significant level of $=0,73$; and the result of learning achievement is $\mathbf{- 0 . 3 1}$ ( t $_{\text {test}}$ )on significant level of $=0,75$. Therefore, it can be concluded that Science learning through flash media and students' worksheet using constructivist approach is effective to improve interest, motivation, and learning achievement of primary school students.
\end{abstract}

Keywords-Constructivist, Flash Media, Worksheet Media, interest, motivation, and learning achievement

\section{INTRODUCTION}

Primary School Education (SD) as part of the national education system has a very important role in improving human resources [1]. Education in primary school is no longer serves as a means of socialization but should be able to grow the potential of students who will be able to play a role as a community changer [2].

Innovations that support learning is required in maximizing the improvement of the learning process at every level of education. The innovations include methods, approaches and media used, as well as the subject of Natural Science (IPA) which is the Science of the natural surroundings and part of the mystery that is in it systematically. Natural Science (IPA) is not just a mastery of a collection of facts and concepts but a process of human discovery as intelligent who are able to think about what and how an event took place. Science learning is emphasized on the provision of experience directly related to a way of discovering and understanding nature surrounding and human being.

It is necessary to improve or to refine the learning process at every level of education in order to achieve the above purposes [3]. The low results of the National Final Examination, greatly influenced by the teacher's behavior on learning in the classroom. Teachers in the process of learning are still using textual context and tend to ask students to memorize the subject. This kind of learning makes students confused in understanding the concepts in Science because the teacher only dictates the subject matter of the book, notes on the board, and instructs the students to memorize everything that has been recorded for the test. Besides wasting a lot of time of listening to teachers in the classroom, students tend to feel confused if there is a Science problem that is done during an exam whose case is not the same as one has memorized before. This difficulty is caused solely by the emphasis on the concept of Science on students that is not done in learning.

The description of problems in Science learning above is the result of the approach used that is still centered on the teacher and the teacher does not involve students in learning activities. It affects students' interest in Science lessons in this school. This can be seen through students who are lazy to do the exercises, do not do homework, do not pay attention to the teacher and not listening to the subject matter Science given. As a result, teachers get difficult in guiding and in controlling students to pay more attention to the lessons at school and learn at home. Students have lack of motivation in learning, for example, many them feels bored with Science subjects, students are more pleased if the times over quickly, students are not active in asking about the Science materials taught by the teacher. As a result, there is no response and feedback from students to teachers on Science subjects so that learning is monotonous and done by the teacher only without involving students. 
The constructivist approach becomes one alternative used by researchers in maximizing learning in primary school. This approach is expected to construct students' initial knowledge, to encourage students in exploring their own knowledge and to provide students with a wider opportunity in exploring what has been previously learned. This constructivist approach encourages teachers to observe students easier and to direct them to the more interesting learning situations.

The use of constructivist approaches is not something new in education world; educators have used this approach quite a lot before. But in the application, the teacher is still monotonous and not varying using media exist, so students are still not maximized in constructing their own knowledge because the basic examples presented by the teacher are still too abstract based on what is observed and the props used are so limited that students are confused to develop their knowledge.

\section{METHODS}

This is a quantitative research using Quasi-Experiment method to compare two different treatments of the research subject. This method is used to overcome the obstacle of control class [4]. In this research, the collection of experimental sampling and control randomly is not conducted.

The experimental group was given treatment in form of Science learning with a constructivist approach using Flash media, while in the control group was given treatment using constructivist approach and students' worksheet media, the study picture that can be done can be seen in Table I below.

TABLEI. EXPERIMENTAL RESEARCH DESIGN [4]

\begin{tabular}{|c|c|c|c|}
\hline Class & Pre-test & Treatment & Post-test \\
\hline $\mathbf{X}_{\text {experiment }}$ & $\mathbf{T}_{1}$ & $\mathbf{P}_{1}$ & $\mathbf{T}_{2}$ \\
\hline $\mathbf{X}_{\text {control }}$ & $\mathbf{T}_{3}$ & $\mathbf{P}_{2}$ & $\mathbf{T}_{4}$ \\
\hline
\end{tabular}

\section{Annotation:}

T1 : Pre-test of Experimental Research

T2 : Post-test Experimental Research

T3 : Pre-test Control Class

T4 : Post-test Control Class

$\mathrm{X}$ experiment : Experimental Class

$\mathrm{X}$ control : Control Class

P1 : Treatment through constructivist approach using Flash media

P2 : Treatment through constructivist approach using students' worksheet media

\section{A. Research Variable}

This research using several variables grouped into two:

\section{1) Independent Variable}

The independent variable in this research is learning through constructivist approach using Flash media in experiment class and constructivist approach using students' worksheet media in control class,

\section{2) Dependent Variable}

The dependent variables in this research are the learning interest of Science, learning motivation of Science and learning achievement of Science in each experiment class and control class.

\section{B. Techniques of Data Collection and Instruments}

1) Technique of Data Collection

Data were collected through pre-test and post-test to measure the previews ability of learning achievement, furthermore interest, motivation of students measured using questionnaire.

\section{2) Research Instrument}

The instrument of this research is a test and non-test. The test is used to measure learning achievement of Science and the non-test is used to measure the interest and motivation in learning Science.

\section{Instrument Validity and Reliability}

\section{1) Instrument Validity}

In this study, the validity used is rational and empirical validity. The rational validity test is obtained on the basis of thinking logically [5]. Empirical validity test is the measurement precision based on the result of the empirical analysis. In other words, empirical validity is derived through or obtained on the basis of observation field [5].

Instruments have rational validity if the criteria that exist in the instrument rationally and theoretically have reflected what is measured. Rational validity in this study is the content and the construct validity.

a. Content validity is a measure that indicates the extent to which the score in the test relates to the mastery of the test participants on the study field tested through the test device. The validity level of contents of the instrument is performed by expert judgment.

b. Construct validity implies that a measuring instrument is valid if it has matched the theoretical constructs on which the instrument was made.

c. Instruments have empirical validity if it is based on the results of the analyslis conducted on observation data field, it is proved that the instrument can accurately measure the learning achievement that should be disclosed or measured. The magnitude of the correlation index between the grain score to the total score can be seen through the Item of Total Statistics output using statistic program in the Corrected Item of Total Correlation field. Scores obtained will be considered to be valid if each item on the instrument is greater than the minimum standard of 0.3 .

\section{2) Reliability}

Instrument reliability is a degree of learning from the instrument in terms of measuring what it measures. An instrument must be able to measure student's ability correctly and appropriately [6]. To know whether a instrument is reliable or not, then it must be able to calculate the reliability coefficient. The instrument of reliability test is performed using an alpha formula from Cronbach using statistic program. The criteria for determining instrument reliability are based on the 
criteria proposed by [7], when the reliability coefficient $\geq 0.7$ is high enough for a baseline research.

The instrument of reliability test is performed after the instrument of validity test, only valid items are tested. The result of reliability instrument test on the interest of Science learning is 0.73 . The interest of learning instrument of Science is reliable if the alpha coefficient is above 0.70 . The result of reliability analysis of learning interest can be seen in appendix 4.d. Furthermore, the result of reliability test of students' motivation to Science subject is 0.71 shows a number above 0.70 which is considered as reliable. The learning achievement of Science subject is 0.703 it shows a number above 0.7 . This means that the learning achievement of Sciences is reliable.

\section{Techniques of Data Collection and Instruments}

\section{1) Technique of Data Collection}

Data were collected through pre-test and post-test to measure the initial ability of learning achievement, while student's interest and motivation were measured by using questionnaire of interest and motivation.

\section{2) Research Instrument}

Instruments in this research design are in form of test and non-test, test instruments are used to measure the learning achievement of Science, the non-test instrument is used to measure the learning interest and motivation of Science.

\section{RESULT AND DISCUSSION}

There are several data in this research, such as pre-test data including questionnaire of learning interest, motivation, achievement test of Science and post-test data including questionnaire of learning interest, learning motivation and achievement test, each data obtained from the control and the experimental class.

TABLE II.HYPOTHESIS TEST 1

\begin{tabular}{|c|c|c|c|}
\hline Test & $\mathbf{t}$ & Sig. & Annex \\
\hline $\begin{array}{c}\text { Learning Interest of } \\
\text { Science } \\
\text { pre-test dan post test }\end{array}$ & $-13,62$ & $0,00<0,05$ & $\begin{array}{c}\text { Ho is rejected and } \\
\mathrm{H}_{1} \text { is accepted }\end{array}$ \\
\hline $\begin{array}{c}\text { Learning Motivation of } \\
\text { Science } \\
\text { pre-test dan post test }\end{array}$ & $-12,18$ & $0,00<0,05$ & $\begin{array}{c}\text { Ho is rejected and } \\
\mathrm{H}_{1} \text { is accepted }\end{array}$ \\
\hline $\begin{array}{c}\text { Learning Achievement } \\
\text { of Science } \\
\text { pre-test dan post test }\end{array}$ & $-8,97$ & $0,00<0,05$ & $\begin{array}{c}\text { Ho is rejected and } \\
\mathrm{H}_{1} \text { is accepted }\end{array}$ \\
\hline
\end{tabular}

Based on Hypothesis test using t test on Table II:

1) Learning interests of Science, Ho is rejected and H1 is accepted it means that learning Science using Flash media effectively increase the learning interest of Science students.

2) learning motivation of Science, Ho is rejected and H1 is accepted which means that learning Science using Flash media effectively improve students' learning motivation.
3) The results of learning Science, Ho is rejected and $\mathrm{H} 1$ is accepted means that learning Science using Flash media effectively improve students' Science learning achievement.

TABLE III.HYPOTHESIS TEST 2

\begin{tabular}{|c|c|c|c|}
\hline Test & T & Sig. & Annex \\
\hline $\begin{array}{c}\text { Learning Interest of } \\
\text { Science } \\
\text { pre-test dan post } \\
\text { test }\end{array}$ & $-8,86$ & $0,00<0,05$ & $\begin{array}{c}\text { Ho is rejected and } \\
\mathrm{H}_{1} \text { is accepted }\end{array}$ \\
$\begin{array}{c}\text { Learning Motivation } \\
\text { of Science } \\
\text { pre-test dan post test }\end{array}$ & $-9,68$ & $0,00<0,05$ & $\begin{array}{c}\text { Ho is rejected and } \\
\mathrm{H}_{1} \text { is accepted }\end{array}$ \\
\hline $\begin{array}{c}\text { Learning } \\
\text { Achievement of } \\
\text { Science }\end{array}$ & $-8,70$ & $0,00<0,05$ & $\begin{array}{c}\text { Ho is rejected and } \\
\mathrm{H}_{1} \text { is accepted }\end{array}$ \\
\hline $\begin{array}{c}\text { pre-test dan post test } \\
\text { Sienced }\end{array}$ & & & \\
\hline
\end{tabular}

\section{Based on Hypothesis test using t test on Table III:}

1) Learning interests of Science, Ho is rejected and H1 is accepted it means that learning Science using students' worksheet media effectively increase the learning interest of Science students.

2) Learning motivation of Science, Ho is rejected and H1 is accepted which means that learning Science using students' worksheet media effectively improve students' learning motivation.

3) The results of learning Science, Ho is rejected and H1 is accepted means that learning Science using students' worksheet media effectively improve students' Science learning achievement.

\section{TABLE IV.HYPOTHESIS TEST 3}

\begin{tabular}{|c|c|c|c|}
\hline Test & T & Sig. & Annex \\
\hline $\begin{array}{c}\text { Learning Interest of } \\
\text { Science Post-test of } \\
\text { Experimental and } \\
\text { Control Class }\end{array}$ & 0,008 & $0,99>0,05$ & Ho is accepted \\
\hline $\begin{array}{c}\text { Learning Motivation } \\
\text { of Science Post-test of } \\
\text { Experimental and } \\
\text { Control Class }\end{array}$ & $-0,33$ & $0,73>0,05$ & Ho is accepted \\
\hline $\begin{array}{c}\text { Learning Achievement } \\
\text { of Science Post-test of } \\
\text { Experimental and } \\
\text { Control Class }\end{array}$ & $-0,31$ & $0,75>0,05$ & Ho is accepted \\
\hline
\end{tabular}

Based on Hypothesis test using $\mathrm{t}_{\text {test }}$ on Table IV:

1) Learning Interest of Science: Ho is accepted, it means that the learning of Science using Flash media significantly not more effective in improving students' interest compare to the use of students' worksheet.

2) Learning motivation of Science: Ho is accepted, it means that the learning of Science using Flash media 
significantly not more effective in improving students' motivation compare to the use of students' worksheet.

3) Learning Achievement of Science: Ho is accepted, it means that the learning of Science using Flash media significantly not more effective in improving students' learning achievement compare to the use of students' worksheet.

\section{CONCLUSION}

Learning Science using Flash and students' worksheet media through the constructivist approach in Primary school can be concluded as follows:

- The use of Flash media is effective to improve interest, motivation, and learning achievement of students.

- The use of students' worksheet is effective to improve interest, motivation, and learning achievement of students.

- The effectiveness of the use of Flash and students' worksheet media is not significantly different in improving interest, motivation, and learning achievement of students in Primary school.

\section{REFERENCES}

[1] Suharjo,Mengenal Pendidikan Sekolah Dasar, Jakarta: Depdiknas, 2006.

[2] Semiawan, Belajar dan Pembelajaran dalam Taraf Usia Dini, Jakarta: PT. Prenhaldo, 2002.

[3] Muslicahch Asy'ari, Penerapan Pendekatan Sains-TeknologiMasyarakat dalam Pembelajaran Sains di Sekolah Dasar, Jakarta: Depdiknas, 2006.

[4] Sugiyono, Metode Penelitian Pendidikan, Bandung: Penerbit Alfabeta, 2009.

[5] A. Sudijono, Pengantar Evaluasi Pendidikan,Jakarta: Raja Grafindo Persada, 2007.

[6] Subiyanto, Evaluasi Pendidikan Ilmu Pengetahuan Alam. Jakarta: P2LPTK, 1988.

[7] R.M. Kaplan, \& D.P. Saccuno, Pysicological Testing, Principles, Applications, and Isuues, Monterey: Brockscole Publishing Comp, 1982. 